\title{
Sine-Gordon Soliton Dynamics
}

\section{Olsen, O. H.; Samuelsen, Mogens Rugholm}

\section{Published in:}

Physical Review Letters

Link to article, DOI:

10.1103/PhysRevLett.48.1569

Publication date:

1982

\section{Document Version}

Publisher's PDF, also known as Version of record

Link back to DTU Orbit

Citation (APA):

Olsen, O. H., \& Samuelsen, M. R. (1982). Sine-Gordon Soliton Dynamics. Physical Review Letters, 48(22), 1569-1569. https://doi.org/10.1103/PhysRevLett.48.1569

\section{General rights}

Copyright and moral rights for the publications made accessible in the public portal are retained by the authors and/or other copyright owners and it is a condition of accessing publications that users recognise and abide by the legal requirements associated with these rights.

- Users may download and print one copy of any publication from the public portal for the purpose of private study or research.

- You may not further distribute the material or use it for any profit-making activity or commercial gain

- You may freely distribute the URL identifying the publication in the public portal

If you believe that this document breaches copyright please contact us providing details, and we will remove access to the work immediately and investigate your claim 


\section{Sine-Gordon Soliton Dynamics}

In recent paper $\mathrm{s}^{1,2}$ Fernandez and co-workers have shown that sine-Gordon solitons do not behave like Newtonian particles under the influence of a constant force. The results are obtained numerically and show that the soliton acceleration starts up very slowly $\left(\sim t^{2}\right)$ and not with a finite value as a Newtonian behavior would require. The results are supported by a perturbation treatment based on a theory by Fogel et $a l .^{3,4}$ On the other hand previous perturbation treatments ${ }^{3-6}$ and experiments in numero ${ }^{7-9}$ show that the sineGordon soliton under the influence of a force behaves like a Newtonian particle. In fact the perturbation results very precisely describe the soliton motion.

Both results are correct. The apparent contradiction is due to differences in the vacuum "motion" in the two cases, i.e., the behavior of solutions at $x= \pm \infty$. In Refs. 1 and 2 the vacuum is in an excited state while the Newtonian behavior is observed with the vacuum in its ground state.

The influence of the vacuum on the soliton motion can easily be seen from Eq. (4) of Ref. 1:

$$
\gamma(t) V(t)=\frac{1}{4} \pi\left(\chi t-d u_{\infty} / d t\right),
$$

where $V(t)$ is the velocity of the soliton, $\gamma(t)^{-1}$ is the width of the soliton \{which for small perturbations is $\left.\left[1-V(t)^{2}\right]^{1 / 2}\right\}, \chi$ is the "force" term in the perturbed sine-Gordon equation

$$
u_{x x}-u_{t}=\sin u-\chi
$$

and $u_{\infty}(t)$ is the vacuum part of the sine-Gordon field $u(x, t), u_{\infty}$ only depending on time, i.e., $u_{\infty}$ alone is a solution to Eq. (2).

Equation (1) clearly shows that the vacuum "motion" through $d u_{\infty} / d t$ influences the motion of the soliton. If the vacuum is in its ground state $u_{\infty}=\sin ^{-1} \chi$, then $d u_{\infty} / d t=0$ for all times, yielding the results of Refs. 3-9. On the other hand, if the vacuum is started with $u_{\infty}=0$ and $d u_{\infty} / d t=0, d u_{\infty} / d t$ starts up as $\chi t$ and thus eliminates the direct action of the $\chi$ term in Eq. (2), yielding the results of Refs. 1 and 2. Other initial conditions of the vacuum would give other initial motion of the soliton.

We have checked the results obtained above numerically ${ }^{10}$ and found good agreement between Eq. (1) and the numerically determined velocities for the different initial conditions of the vacuum. Various numerical definitions of the velocity have been used and they all show the same qualitative agreement with the theory. ${ }^{10}$

O. H. Olsen

M. R. Samuelsen Physics Laboratory I The Technical University of Denmark DK-2800 Lyngby, Denmark

Received 13 October 1981

PACS numbers: $03.20 .+i$

${ }^{1}$ J. C. Fernandez, J. M. Gambaudo, S. Gauthier, and G. Reinisch, Phys. Rev. Lett. 46, 753 (1981).

${ }^{2}$ G. Reinisch and J. C. Fernandez, Phys. Rev. B 24, 835 (1981).

${ }^{3}$ M. B. Fogel, S. E. Trullinger, A. R. Bishop, and J. A. Krumhansl, Phys. Rev. Lett. 36, 1411 (1976), and 37,314 (1976).

${ }^{4}$ M. B. Fogel, S. E. Trullinger, A. R. Bishop, and J. A. Krumhansl, Phys. Rev. B 15, 1578 (1977).

${ }^{5}$ D. J. Kaup and A. C. Newell, Proc. Roy. Soc. London, Ser. A 361, 413 (1978).

${ }^{6}$ D. W. Mc Laughlin and A. C. Scott, Phys. Rev。A 18 , 1652 (1978).

${ }^{7} \mathrm{P}$. L. Christiansen and O. H. Olsen, Wave Motion $\underline{2}$, 185 (1980)。

${ }^{8}$ O. H. Olsen and M. R. Samuelsen, Phys. Scripta 23,1033 (1981).

${ }^{9}$ O. H. Olsen and M. R. Samuelsen, Phys. Rev. B $\underline{25}$, 3181 (1982).

${ }^{10} \mathrm{O}$. H. Olsen and M. R. Samuelsen, to be published. 